\title{
和歌山大学学生自主創造科学センターにおける 自主性創造性教育方法の開発と推進
}

Development and Promotion of Education Method for Independent and Creative Study at Student

Center for Independent Research in the Sciences of Wakayama University

$\begin{array}{cllll}\text { 森 本 吉 春*1 } & \text { 宮 永 健 史*2 } & \text { 尾久土 正 已*3 } & \text { 藤 垣 元 治*4 } \\ \text { Yoshiharu MORIMOTO } & \text { Takeshi MIYANAGA } & \text { Masami OKYUDO } & \text { Motoharu FUJIGAKI }\end{array}$

In order to educate independent and creative study, Wakayama University started "Systems Engineering Independent Study" when Faculty of Systems Engineering was established in 1996. Developing this education, Wakayama University established Student Center for Independent Research in the Sciences. This center treats various programs to encourage university students as well as pupils in the local community. In this paper, these activities and the evaluation are introduced.

Keywords : Engineering education, Student, Seminar, Creativity, Education effect, Education for independent and creative study, Creation education, Student Center for Independent Research in the Sciences, Independent study, Contest of independent study for student, Work study, Interesting science festival

キーワード：工学教育, 学生, 演習, 創造性, 教育効果, 自主性創造性教育, 創成教育, 学生自主創 造科学センター, 自主演習, 学生自主研究コンクール, 体験学習, おもしろ科学まつり

\section{1.はじめに}

最近, 若者の学力低下が問題となっている. 特に, 自ら課題を見つけ研究し, 解決する能力や, 創造的能 力は不十分であると言われている。科学技術創造立国 を揭げる日本を担っていく若者は，ぜひこのような能 力を備えねばならず，そのような教育は益々重要とな る。そこで，和歌山大学では学生の自主性創造性を育 てるための教育活動を積極的に行っている。1996年 のシステム工学部発足に当たっては, 今までの大学教 育で重視されてきた知識の詰め込みの人材を養成する のでなく, 自主的に物事を考え, 創造的に課題を解決 する能力のある学生を養成することを特色とした。

具体的には, 学力偏差值の高い学生よりも自主性創 造性の高い学生を確保するために，後期入試では総合 問題を課すこととした，教育面においては，学生の自主 的創造的能力を伸ばすため, 学生が自分の興味あるこ とを自主的に行った場合に単位として認定する, 他大学 にない科目「システム工学自主演習」を開設した，さら に, この科目に取り組む学生を支援するため, 種々の活

平成 18 年 1 月 31 日受付

※ 1 和歌山大学

$※ 2$ 和歌山大学教育学部

※3和歌山大学学生自主創造科学センター

$※ 4$ 和歌山大学システム工学部
動を行ってきた. 2001 年より, 全学的取組とするため, 学内組織として「学生自主創造科学センター（愛称ク リエ)」を発足させた。同時に, 新たに教育学部生を対 象とした「教育学部自主演習」や全学学生を対象とし た「自主演習」科目も開設した．今までに多くの学生が これらの自主演習科目を履修している.

さらに, 和歌山大学の学生だけでなく他大学, 高専, 高校の学生生徒を含めた自主的創造的活動を支援し評 価するため, 1998年より「学生自主研究コンクール」 を開催している. また, 若者の理科離れを防ぐため, 小・中・高校の生徒や一般市民を対象とした「公開体 験学習会」,「おもしろ科学まつり」,「講演会」などを 行っている. これらの活動は, 本学教員をはじめ多く の方々のボランティア活動や地域の支援によって支え られている。

これらの活動が，2003年から募集が始まった文部科 学省の「特色ある大学教育支援プログラム (特色 GP)」 に採択された．本文では，これらの活動について紹介す るとともに，それらの活動によって起った学生の意識の 変化などをアンケート結果などにより評価する。

2. 学生自主創造科学センターの設置の目的と設 置までの経緯

1995年のシステム工学部設置に当たって, システム 


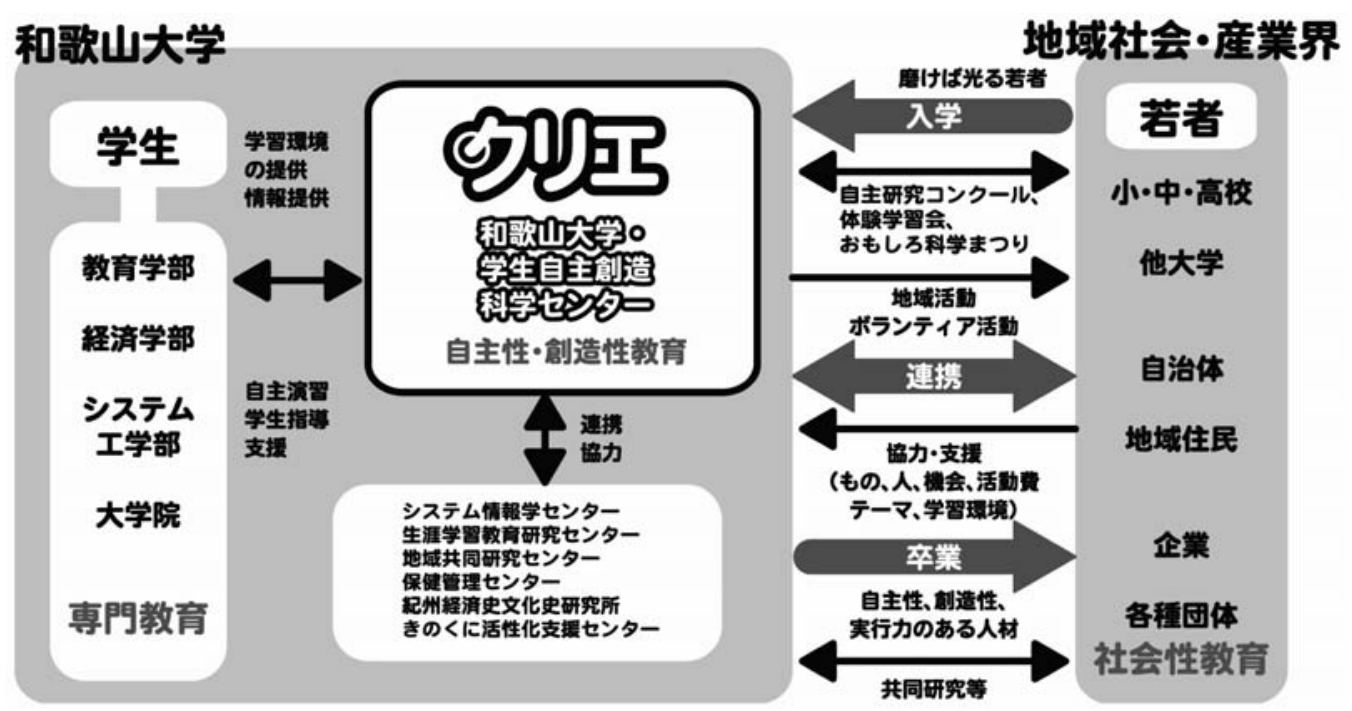

図 1 和歌山大学学生自主創造科学センターの学内外での位置づけ

工学部設置準備委員会で, 自主性創造性ある学生を育 成することを教育戦略とした，そこで，学生の自主的な 研究活動に単位を与える科目「システム工学自主演習」 を1996年の一期生入学時に開設した。これに取り組む 学生を支援するために学生のためのセンターを設置する ことを目指し，1998年にシステム工学部内に「学生自 主創造科学センター（仮称）設置準備委員会」を設け た.この委員会において, 組織的に種々の活動を始め た。また，「システム工学自主演習」の活動の資金を支 援し，その成果の評価をおこなうため，1998年より「学 生自主研究コンクール」を開催した，政府は，科学技術 創造立国を提唱しているが, 小・中・高校で理科離れ が進んでいるため, 大学で教育を行うだけでは, これに 対応するだけの人材を養成することはできなくなってき ている. そこで, このコンクールでは, 和歌山大学の学 生だけでなく, 地域の若者の理科離れを防ぐために, 他 大学, 高専, 工業高校, 普通高校も含めた自主研究を 発表する場とし, 地元企業の主催により実施した。この ようにして, 地域の若者全体の自主的創造的教育を推 進する活動に発展した。

また，センターを設置するためには，システム工学 部だけでなく, 全学的戦略活動とし，1999年には全 学的な「学生自主創造科学センター検討会」が発足し た.この検討会のもとで, 地域の若者に, 科学的体験 をさせて, 科学に興味を持たせ, 理科離れを防ぐため の活動を企画し,「公開体験学習会」,「打もしろ科学 まつり」など多様な活動を和歌山大学の教員や学生が 実施した。これらの活動を，資金面で支援するため， 地元の多数の企業に資金援助を打願いした。 さらに, より活発にこれらの活動を行うため, 2000年より文 部科学省に省令施設としての設置を概算要求してき た。その後, 2001 年に学内措置として他大学に例の ない「学生自主創造科学センター (愛称クリエ)」を 設置した。 2003 年には，新設の総合研究棟に 150 平米
の部屋を確保し, 工作機械などの設備機器を設置して いる. また同時に, 学長裁量による任期制の専任教員 を配置している。

前述のようにクリエは, 若者の自主的創造的科学活 動を促進することを目的として, 建物・設備・指導 者・資金等の面で支援を行っている. 図 1 に示すよう に，大学全体による基礎教育，および各学部での専門 教育をコアに, クリエは自主性創造性教育を, 地域社 会や産業界は社会性教育を主として行い，これらの連 携をとることによって, 総合的能力のある人材を育成 し, 輩出することにより, 地域社会や産業界に貢献す る. クリエは, 大学内の各学部や各センター, 大学外 の地域社会や産業界との連携を通して, 本学の学生を 始め地域の若者の自主的創造的科学活動を支援 - 促進 する教育をしている.このように和歌山大学は, 科学 技術創造立国に貢献できるように，積極的に科学技術 離れを防ぐ活動や, 社会の要求にあった人材の育成を 行っている.クリエの活動を通して自主性創造性教育 の開発, 大学の個性化, 地域社会や産業界との連携を 目指している。このような学生の自主的創造的な活動 を中心に据えたセンターは日本で初めてである。この 具体的諸活動を以下に詳しく説明する。

\section{3. 具体的活動}

3. 1 「自主演習」と「自主演習プロジェクト」

「自主演習」は, 学生が自主的に行った科学的活動 に対して単位を与える日本初の授業である.ソーラー カーやロボット製作などのように学生が好きなテーマ に取り組むことができる。 1 年生から 3 年生の学生が 履修することができ（教育学部自主演習は 4 年前期ま で, システム工学特別自主演習は修士 1 年 2 年前期 まで履修可能), 学生が学部学科を問わず指導教員一 人をみつけ，自主的な研究計画を示してその教員の同 意を得て, 履修届を提出する. その教員の指導のもと 


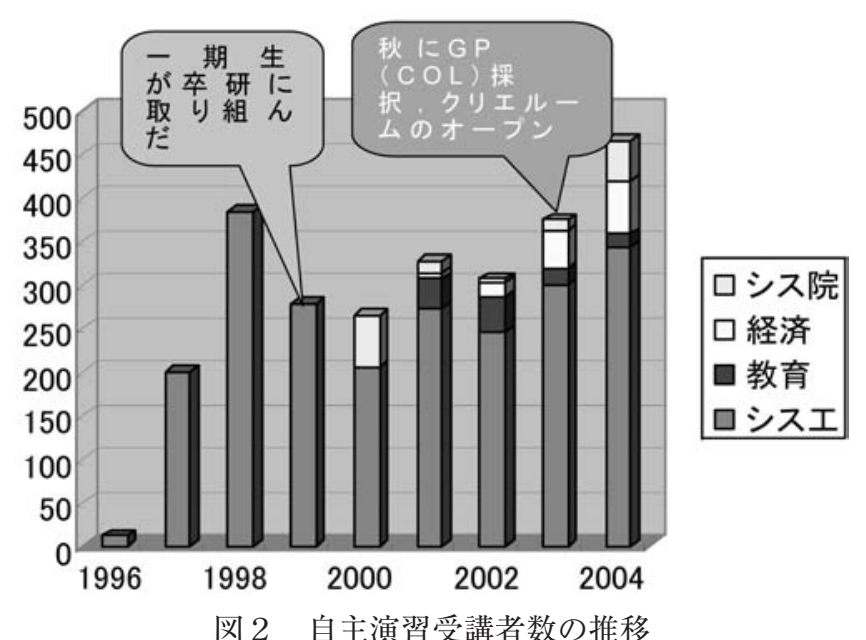

研究活動を行い, 報告書や作品を提出し, 評価される ことにより単位が取得できる（半期単位の履修で 1 単 位の授業である)，前述のように1996年にシステム工 学部で開始され，2001年からは全学で行われている. 工学系だけでなく，人文社会系の学生に対しても自主 性や創造性を高める教育の場となっている.

クリエは, 学生を指導するための指導教員を登録し, 指導可能分野を紹介している，指導教員として100名 以上の教員が登録している．指導教員として登録され ている教員以外でも, 学生が交涉して自主演習の指導 教員になってもらうことができる。また，クリエは建 物や設備の貸与，工作機械などの技術的支援，資金的 支援を行っている.

学生が自主的に課題を見つけ実行することにより単 位を取得できるので，その人気は高い。受講希望学生 は多く，1996年度より，2005年度前期までに 2,791 名 が受講している。初年度は，システム工学部の教員が 1 期生のみを相手に自主演習を指導していたが，図 2 に示すように，学年進行とともに 2 期生， 3 期生と学 生が増え, 自主演習が増加した。しかし，1期生の卒 業研究が始まると, 教員もその指導に忙しくなり自主 演習の件数が減少している. その後, 特色 $\mathrm{GP}$ の採択 により, 予算が増え, 専用の場所や設備などが整備さ れたことにより，また，自主演習の受講者が増加して いる.

自主演習活動を資金的に支援するために，希望する 指導教員には 2 万円までの消耗品を支給している。 た，高額の資金を必要とする活動に対しては，2002 年より,「自主演習プロジェクト」としてプロジェク 卜を募集し, 採択された数件のプロジェクトに対して, 10 万円〜 100 万円の消耗品の提供を行っている. なお， 自主演習は半期単位で履修するが, 自主演習プロジェ クトは通年で行っている.

また，自主演習の成果を発表する機会も多く設けて いる. 和歌山大学で行われている高校生向けのオープ ンキャンパス, 一般向けの公開体験学習会, 小中学生 向けの括もしろ科学まつりにおいても, 学生が主体と

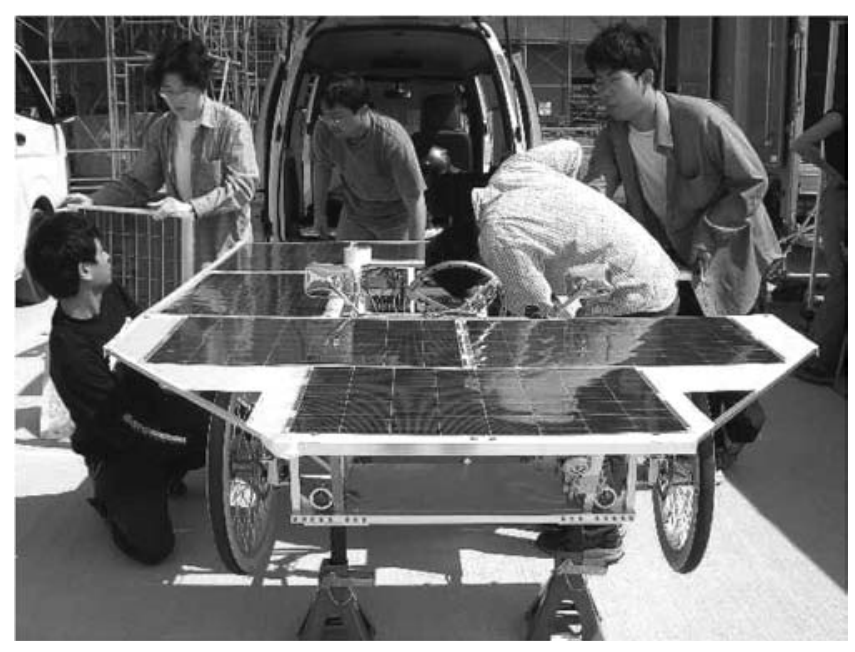

図 3 ソーラーカーラリー（Eco Car Fest 2005 於 : 神戸空 港）に出場したソーラーカー

なり展示内容を決め, 準備と説明を行っている.これ らのことが, 相手に合わせて説明するよい練習となり， コミュニケーション能力の向上につながっている. 自 主演習の実施により, 学生自主研究コンクールでの入 賞だけでなく，国際的コンクールで受賞した学生もお り，大きな成果をあげている。一例として，自主演習 で製作したソーラーカーの写真を図 3 に示す.

\section{2 学生自主研究コンクール}

自主演習活動を資金的に援助し，その活動成果を発 表し、それを評価するために，1998年より「学生自 主研究コンクール」を開催している. 毎年数十件の応 募の中から, 年度初めに 30 件程度を選抜して活動資 金を補助している。年度末にその活動成果を発表して もらい, 優秀なものを表彰している. 和歌山大学の学 生だけでなく, 和歌山県下の高校, 高専, 大学の生 徒・学生を対等に評価するという新しいコンクールで ある。

当初は, 本学の要請により地元企業の主催で行われ てきたが, 2002年度からは本センターの主催, 地元 企業の協賛で行っている. 実行委員会は, 県下の大学, 高専, 工業高校, 普通高校及び企業から派遣された代 表者で構成されており，自主性創造性教育に関心の高 い教育者の討論と実行の場所となっている，高校，高 専, 大学の生徒・学生を対等に評価し, 活動資金を補 助している. 和歌山県下の学生にとっては学外者との 競争であり，良い刺激となっている，最優秀賞や優秀 賞を取るプロジェクトはすばらしい内容であり, 特許 を出すような成果も出ている. 地元テレビでの番組と しての放映や，ニュースとしての放映により，多くの 県民に創造性教育の面白さを伝えており，理科離れの 対策に貢献しているといえる，特に毎回良い成績をあ げている工業高校生の能力を評価する良い機会にもな っている.

\section{3 公開体験学習会}

十年余り前から大学祭時に, 和歌山大学の教員の有 
志が種々の公開体験授業を行ってきたが，1999年度 から本格的に大学行事として実施している. 大学の最 新のハイテク実験装置やマルチメディアを用いて, 地 元小・中・高校生や一般市民に公開する催しであり， 大学祭行事として定着している. 科学技術への興味や 関心をもってもらうょうに, 新しい学問内容をわかり やすく紹介している. 自主的に参加したボランティア 教員や学生により運営している. 公開体験学習会や後 述のおもしろ科学まつりは, 児童, 生徒, 市民に科学 の怙もしろさを伝えるだけでなく, 出展に参加してい る学生に対しても, 企画力, 実行力, プレゼンテーシ ヨン能力などを育て, 自主性創造性教育としても大き な成果を挙げている。2004年は33件の展示が行われ, 約 1,000名が参加している. 県下の中学・高校から団 体としての参加もあり，年を追って盛り上がってきて いる. アンケート結果では, 日本オオカミ展示, 環境 問題, 光と画像の拀もしろ体験, ロボット展示などが 人気がある。また，次回も参加したいという意見が大 部分である，企業からの参加者も来ており，大学の最 新の設備を見るだけでなく, 説明している学生の能力 をみて，その企業に引き抜かれた学生もいる。

\section{4 おもしろ科学まつり}

大学生, 小・中・高校・大学の教員, 一般市民有志 が, 科学の実験観察を多数準備し，それらを会場を訪 れる児童生徒や市民に体験してもらって, 科学の楽し さすばらしさを実感してもらう活動である．全国の多 くの会場で開かれている「青少年のための科学の祭典」 の 1 つとして毎年和歌山市で開催している.クリエは, 2001 年に設立されて以来共催団体として積極的に参 加している．2004年からは主催団体の一つとして参 加し，2005年は実行委員会事務局をクリエに置き， 中心的役割を果たした。来場者数は， 3,000 人から 6,000 人である。来場者アンケートでは 9 割の人が 「扔もしろかった」,「来年も来たい」と答えて打り, 児童生徒や市民に科学に親しむ場を提供する点で大き な成果を上げている.

クリエの運営委員や多数の学生が出展や運営に参加 している. 出展する学生は, 自主的にテーマを企画, 実行する中で自主性創造性教育がなされる，教育学部 では, 中学校教員 1 種免許 (理科) 取得に必要な科目, $\lceil$ 中等理科教育法 B」の受講生全員におもしろ科学ま つりへの出展を義務づけている。受講学生の中には 「学生生活の中で最も充実した日々であった」と評価 する者もいる. 反省点としては, 会場が大変混雑した ことや，ものづくりなどのブースで定員をオーバーし て参加できなかった人があったことなど，運営面で改 善する必要もあった。この催しは新聞, テレビ, ラジ オなどのマスコミにも詳しく報道されている.

おもしろ科学まつりは, 和歌山市以外でも開催され ている. 2002年に田辺市, 2004年に新宮市, 2005年
に橋本市で開催された大会には, クリエの支援のもと で学生, 教職員が多数出展した.

\section{5 その他の活動}

\section{(1) 講演会の実施}

2001 年より, 学生の自主性創造性を育てる講演会 を開催している. 和歌山大学の学生や, 教職員はもと より, 地域の市民や高校生などを対象に, 発明, ベン チャービジネス, NPO, 地元ベンチャー, 自主的創 造的取組などに関する講演会を実施している.

(2) シンポジウムの実施

2003 年度の特色 GPに採用されてから, 自主性創造 性教育に関する講演会を開催している。2003年度は, 「大学に打ける自主創造教育シンポジウム」を, 2004 および 2005 年度は「科学コミュニケーション」のシ ンポジウムを開いた。

\section{(3) 写真コンテストの実施}

自主演習や体験学習会など学生の活動に関する写真 のコンテストを開催し, 入賞者へ消耗品の支給を行っ ている，応募した写真は広報に利用している。

\section{(4) 重点テーマの実施}

数年間継続するテーマを設定し, 先輩学生の行った 研究を引き継ぐようにして, 最終的に高度なレベルの 成果を出せるようにしている，学生は交代するので, テーマ担当の教員を決め, 継続的に発展するよう準備 している. 現在,「環境センシング」「若者の理工系離 れ対策」「ベンチャービジネス支援」のテーマを実施 中である.とくに環境センシングの一環として, ミニ アメダスシステムや天文教育システムを開発してい る。若者の理科離れ対策だけでなく，IT教育にも貢 献している。これらの活動は, 県教育委員会などの協 力も得ている.

(5) 企業提案テーマの実施

学生の自主性創造性教育に関心を持っている企業 が，教育テーマを提案し，その指導を行う。企業の社 長によるベンチャービジネス実践講座として, 企業提 案のテーマを企業と学生とが共同でプロジェクトをつ くって実施している。この実施により, 海外の関連会 社でのインターンシップを希望する学生もでてきてお り, 学生の意欲が向上している.

（6）シニアアドバイザー

さまざまな技能・知識・経験を持っている地域の方 にボランティアとして自主演習をサポートする組織を 作る新しい試みである。学生が自主演習に取り組む中 で出てくる「困った」「こんな技術や知識を持った人 に話を聞きたい，助けてほしい」など，さまざまな声 に対して相談できるように，自主演習とシニアアドバ イザー登録者とのマッチングを進めている。これまで に26名の方にシニアアドバイザーとして登録してい ただいている.

(7) 安全講習 
多くの学生に自主演習を安全に履修してもらうため に, 安全講習を毎年行っている。安全講習を履修した 学生には免許証を発行し, 免許証をもつ学生は, 工作 機械を自主演習に利用することができる.

（8）工作教室

もの作りの楽しさを学生に広め, 自主演習にとりく むきっかけを作るために工作教室を行っている．2005 年度には電子工作教室を 2 回行った. 公開体験学習会 では, 電子工作教室に加えて金属加工教室を行った。

(9) 機器貸し出し

自主演習などで必要な機器の貸し出しを行っている. デジタルカメラやビデオなどの映像機器, パネルやプロ ジェクターなどの展示用機材, ライトや台車など屋外作 業用機器, その他に工作機器や計測機器などがある.

\section{4. 学生自主創造科学センターの運営組織}

すでに述べたように省令施設としてのセンターの設 置を検討するために, 1998年にシステム工学部で, 「学生自主創造科学センター (仮称) 検討会」を設置 した.1999年に, 全学的に取り組むことになり，各 学部から選ばれた委員で検討し, 文部科学省へ省令施 設としての「学生自主創造科学センター (仮称)」の 予算要求をしてきた。しかし, 省令施設としては, な かなか認められず, 2001 年に学内センターとして 「学生自主創造科学センター (愛称クリエ)」を自主的 に発足させた. 組織はできたものの, 建物設備はなく, このセンターの活動の企画, 運営は, 各学部代表で構 成される運営委員会を中心として行われ, 諸事業は, 運営委員とそのオブザーバー委員, 「自主演習」の指 導教員など, 多数の教員の協力のもとに各教員の研究 室などで実施されてきた。これにより，組織的に自主 性創造性を伸ばす活動が促進され, さらに, 本学教員 の協力やセンター活動に賛同する自治体及び企業から の人的・財務的・技術的支援を獲得する努力をしてき た. 2003 年に新設の総合研究棟に建物設備を確保し, 学長裁量による専任教員も配置され, 本格的な活動が できるようになった，和歌山大学は工作センターがな いが, クリエはその機能も補っている.

実際の運営は, 各学部から選出された教員, 事務職 員, 高大連携の一環として長期研修をしていただいて いる高校機械科教諭, それに大学院生と大学生からな るティーチングアシスタント拈よび準ティーチングア シスタントによって行われている。 また, オブザーバ 一委員として各学部の 10 名の教員にセンターの活動 に協力してもらっている.

運営経費は, 当初は, 本センターの活動に共鳴した 地元企業からの奨学寄付金だけで行ってきた．地元企 業 17 社からこれまでに奨学寄付金2,490万円の支援を 受けている. 現在は, 特色 GPの予算を主として, 学 長裁量経費, 大学特別経費, 特別事業経費, 経常経費,
寄付金でまかなっている.

\section{5. 学生自主創造科学センターの活動の成果と評価}

和歌山大学の学生の自主性創造性教育に対する取組 は古く, 組織的戦略的に大規模で行っており, 多くの 実績をもっている.クリエの設置により, 学生の自主 的創造的活動がさらに活発化した。このことを客観的 に評価するために，2004年度の自主演習プロジェク 卜と公開体験学習会の出展, そして 2005 年度のおも しろ科学まつりに参加した学生に対して意識調査を行 った。図 4 に示すように, 自主演習プロジェクトは, 学生の約 8 割が自身の自主性, 創造性の向上を感じて いる. 公開体験学習会においても, 出展した学生のう ち半数以上が, 自身の自主性, 創造性の向上を感じて いる.ささに, 打もしろ科学まつりに出展した学生も, その約 8 割が自身の自主性, 創造性の高まりを意識し ている. 自主演習プロジェクトやおもしろ科学まつり に比べて, 公開体験学習会において, 向上を感じた学 生の割合が低くなっているのは, 自主演習プロジェク トが 1 年間を通じて行うものであること，また，おも しろ科学まつりのアンケート対象者が, 関連した理科 教育の授業の受講生であったことに対して, 公開体験 学習会での取り組みが短期間で終わっていることが原 因と考えられる.ささに, 公開体験学習会の参加者や 学生からのアンケートによれば, 本センターの活動が 支持され，さらなる発展が望まれている.

また, 地域社会や産業界へのアンケートでも, 本セ ンターの有効性が認められ, その活動が評価されてい る. 和歌山大学の外部評価委員会でも, この活動が高 い評価を得ている. 地元企業からも, クリエの活動に 賛同する 40 社以上に登録していただき, 活動支援や 寄付をしていただいている。 このように, その教育目 的や効果は学内外で広く認められ, 大きな支援をいた だいている。

これらの活動の取組が特色 GP として採用された が，その採択理由は以下のようになっている.

\section{(採択理由)}

この取組は，和歌山大学の教育目的・教育方針であ る《個性輝く存在感のある学問の府の創造》を実現す るため, 和歌山大学全学の合意によって設置された全 学センター「学生自主創造科学センター」の活動です. 取組実績についても平成 8 年度の「自主演習」科目開 設時からはすでに 8 年にわたって組織的に実施されて いる取組であり, 関係者の努力によって当初目標とし た和歌山大学の学生を始め地域の若者の自主的創造的 科学活動を支援・促進するという目的を達成するなど 大きな成果を上げていると評価されました，この取組 は特に, 大学と地域社会・産業界を結びつける学部レ ベルのブリッジ・プログラムとして優れた特色があ り，他の大学の参考になる事例と思われます。 


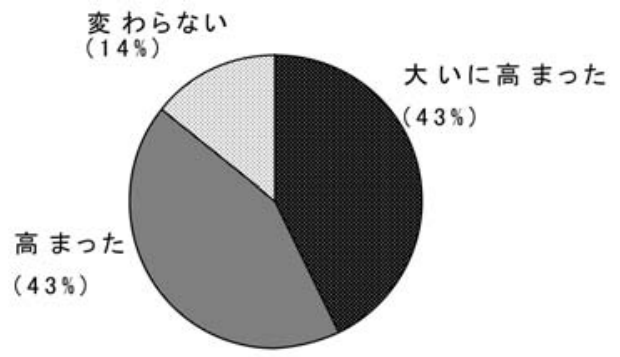

（a）自主演習プロジェクトに参加してあなたの自主性はど うなりましたか?（8プロジェクト，14人からの回答）

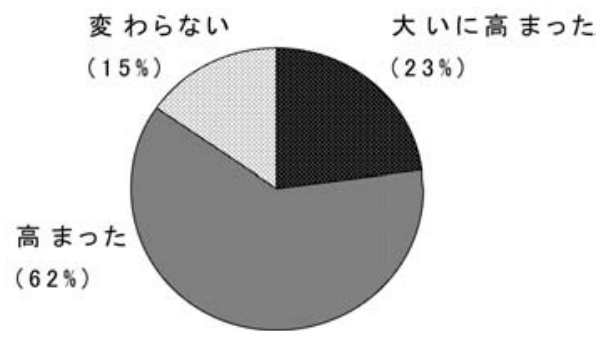

（b）自主演習プロジェクトに参加してあなたの創造性はど うなりましたか?（8プロジェクト，14人からの回答）

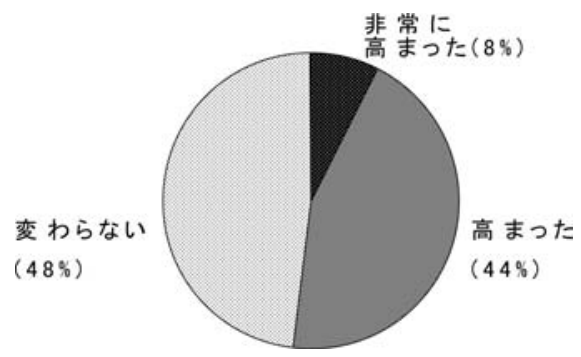

（c）公開体験学習会に出展して自身の自主性，創造性は高 まりましたか?（20ブース，106人からの回答)

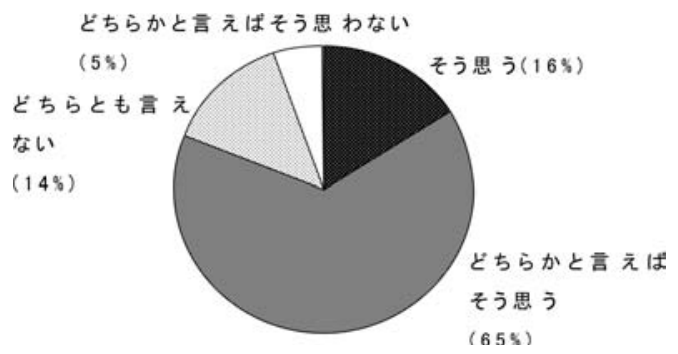

（d）おもしろ科学まつりに参加して，自主的に考えたり, 活動したりする力がついたと思いますか？

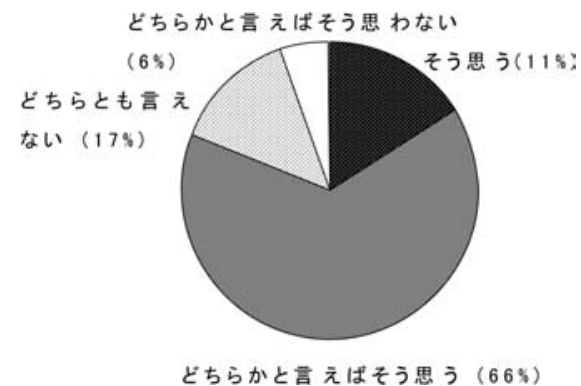

（e）おもしろ科学まつりに参加して，自主的に考えたり， 活動したりする力がついたと思いますか?

図 4 クリエの活動に参加した学生の自主性, 創造性に関 する意識の変化
現在, クリエについては, 多くの他大学からの見学 や問い合わせがあり，いくつかの大学が同じような取 り組みを始めている。 センター活動の成果はホームペ ージ (http://www.crea.wakayama-u.ac.jp/) やパン フレットや活動報告書にて公開している。 ホームペー ジのアクセス回数は 1 年で約 22 万回である. その内 訳は，検索エンジンなどを除いても，和歌山大学以外 からのアクセスが非常に多い. 企業からのアクセスも 多いのが特徴である。

\section{6.おわりに}

上記のように，クリエの活動を通じて，若者の自主性 創造性教育を行ってきた。 その成果も出ている. 今後は この活動をさらに発展させ，世界的水準の教育研究が できる組織や施設を充実させていく，和歌山大学だけで なく，和歌山県から，近畿及び日本全体へと範囲を拡 げ，日本における学生の自主的創造的活動の拠点とし て，学生の自主性創造性教育に関する国内会議や国際 会議, さらに全国規模のコンクールを開催したい。他大 学にない活動を通して大学の活性化を図っている.

さらには，企業提案の共同研究的テーマを学生が実 施するようにしたい.このような学生は，実社会で役立 つ能力と勉学志向と目的意識を身につけ, 企業をよく 知ることができ, 就職してからのミスマッチを減らすこ とができる．企業にとってもこれらの活動により，良い 人材を確保する求人活動にもなる。逆に，学生の自主 的テーマを企業に対して提案し，そのテーマの実施を引 き受ける企業でインターンシップを行う。また，海外の 企業や大学におけるインターンシップも可能とする.

また，科学コミュニケーターの養成も教育学部など と連携しながら進めている。ささらに，子供たちに，も のづくり企業を理解していただくための, 子供向け企 業紹介なども行いたい。さらには，文系の学生の自主 性創造性を高める活動も行いたいと考えている。しか し, 国立大学の独立行政法人化により, 教職員は益々 忙しくなっており, 大学だけでなく, 退職者など地域 社会を含めた取組が大事と考えている.

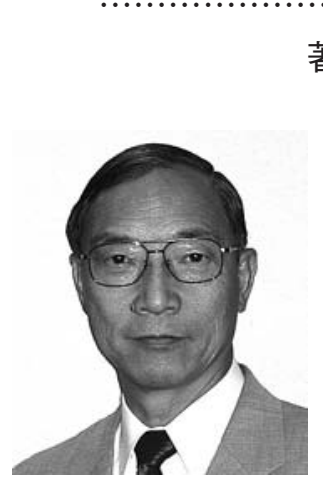

著者紹介

森本 吉春

1966 年大阪大学基礎工学部機械工学科卒. 1968年同大学院修士課程修了．同年株式会 社小松製作所入社. 1974 年大阪大学基礎工 学部機械工学科助手, 1981年工学博士（大 阪大学)，1981 年講師，1985 年助教授. 1993年和歌山大学経済学部産業工学科教授. 1995年システム工学部創設準備室教授を経 てシステム工学部光メカトロニクス学科教 授, 2005 年研究・社会連携担当理事, 現在 に至る. 実験力学, 画像計測の研究に従事. 